Kelaniya Journal of Human Resource Management

Volume 10-Number 01-January 2015 \& Number 02-July 2015

\title{
The Impact of Total Quality Management Practices on Export Performance of Apparel Exporters in Sri Lanka
}

\author{
M. W. B. Abeykoon ${ }^{1}$ and Chamaru De Alwis ${ }^{2}$ \\ ${ }^{1}$ Department of Commerce, Ministry of Industry and Commerce, Sri Lanka \\ ${ }^{2}$ Department of Human Resource Management, University of Kelaniya, Sri Lanka \\ 1bhagya325@yahoo.com, 2dealwisac@gmail.com
}

\begin{abstract}
In today's global competition and economic liberalization, quality has become one of the important factors in achieving competitive advantages. Hence, the quality and its continuous advancement has developed a significant meaning for todays' business. Developed countries often resist exports from developing countries if the exports do not meet their country quality standards. Sri Lanka like other developing economies is also trying hard to exploit business opportunities in international markets and has succeeded as far as textiles and apparel industry. Purpose of this study was to examine the impact of Total Quality Management Practices (TQMP) on Export Performance (EP) of apparel exporters of Sri Lanka. A five point Likert scale questionnaire was used as the key instrument of data collection and data were obtained from 65 apparel exporters in Sri Lanka. Eight dimensions were used to measure TQMP including Leadership, Training, Employee Management, Information and Analysis, Supplier Management, Process Management, Customer Focus and Continuous Improvement. The regression and correlation analysis were used to examine the impact of $T Q M P$ on EP and the relationship between TQMP and EP.

Results of the study clearly indicated that all dimensions except Information and Analysis were significantly correlated with EP. In addition, Customer Focus, Continuous Improvement and Supplier Management were found as the most significant dimensions that impact on EP.
\end{abstract}

Keywords: Total Quality Management Practices, Export Performance, Apparel Exporters 


\section{Introduction}

In today's global competition and economic liberalization, quality has become one of the important factors for achieving competitive advantage. There is an ever-increasing demand for quality product and/or services and this global revolution had forced organizations to invest substantial resources in adopting and implementing total quality management strategies. The present day international market environment is characterized by increased number of competitors and intensified efforts at all levels and each domain. Under these circumstances quality development and its continuous advancement has developed a significant meaning. The world market demands quality and it has become the matter of survival. Linder (1961) first noted the role of product quality on trade. He argued that richer countries have a comparative advantage in the production of high-quality goods. Developed countries often resist exports from developing countries, if the exports do not meet their country quality standards. In order to increase exports to developed countries, more and more enterprises choose to adopt international standards to reduce consumers' uncertainty about the quality of products and thus increase selling in the market (Uzumeri, 1997). Exports of a country play an important role in the economy. International market the empirical results confirm that the rich countries import relatively more from countries that produce high-quality goods. Even though traditional determinants of comparative advantage are still the main driving force of trade, quality differences between countries have a significant effect on the pattern of international trade flows (Hallak, 2003).

Total Quality Management (TQM) is now considered by virtually all leading firms and quality practitioners as the way forward, to gain a competitive edge (Goh \& Ridgway, 1994). Moreover, Valos \& Baker (1996) established that systems such as total quality management were vital ingredients in a firm's overall capability, suggesting that a mere increase in production competencies is inconsequential to export performance.

Although there is a considerable increase in the publication of research work dealing with TQM, few studies explores the relationship between various factors and the adoption of TQM practices by firms. In addition, the controversy about the importance of TQM in improving the corporate 
performance leads various researchers to identify factors behind this controversy.

Sri Lanka like other developing economies is also trying hard to exploit business opportunities in international markets and has succeeded as far as textiles and apparel industry. The textile and garment industry of Sri Lanka has risen from its modest beginnings in the 1950s to become the countries' largest industrial sector, demonstrating tremendous growth over the last three decades (Kelegama, 2009).

According to a research conduct in Sri Lanka by Kapuge \& Smith (2005) on Management Practices and Performance Reporting in the Sri Lankan Apparel Sector, It was anticipated that garments companies which had implemented TQM would be pursuing a high quality strategy, and delivering a high quality performance.

Therefore, purpose of the study is to analyze the impact of total quality management practices used by apparel exporters on export performance. In particular, the analysis focused on identifying the levels of TQM practices used by the Sri Lankan exporters and impact of those practices on export performance.

The main objective of the study was to identify the Impact of Total Quality Management Practices on Export Performance of Apparel Exporters of Sri Lanka. In addition to that the study aimed to identify the levels of TQM practices used by the Sri Lankan apparel exporters.

\section{Literature Review}

\subsection{Definitions of Total Quality Management (TQM)}

Different authors have given various definitions of Total Quality Management, TQM is a strategy which is concerned with changing the fundamental beliefs, values and culture of a company, harnessing the enthusiasm and participation of everyone (Atkinson \& Naden, 1989).

The first largely dimensioned implementation of Total Quality Management was made by Toyota as a part of their lean production strategy. The concept of TQM is mainly used to improve the quality of the end product and to 
Kelaniya Journal of Human Resource Management

Volume 10-Number 01-January 2015 \& Number 02-July 2015

reduce deficiencies in the production which leads to cost reductions (Juran, 2000).

\subsection{Total Quality Management Practices}

Different studies performed by various scholars have identified several TQM practices. The TQM Practices identified in measurement studies carried out around the world in recent years summarized by Hassan, Malik, \& Faiz (2012) is as follows.

Table 01: TQM practices identified in measurement studies carried out around the world in recent years

\begin{tabular}{|l|l|c|c|c|c|c|c|c|c|c|c|c|c|}
\hline \multirow{2}{*}{ No } & \multicolumn{1}{|c|}{ Authors } & \multicolumn{7}{|c|}{ Critical Success Factors of TQM } \\
\hline & & $\mathbf{1}$ & $\mathbf{2}$ & $\mathbf{3}$ & $\mathbf{4}$ & $\mathbf{5}$ & $\mathbf{6}$ & $\mathbf{7}$ & $\mathbf{8}$ & $\mathbf{9}$ & $\mathbf{1 0}$ & $\mathbf{1 1}$ & $\mathbf{1 2}$ \\
\hline 1 & Rahman (2001) & $\sqrt{ }$ & $\sqrt{ }$ & & $\sqrt{ }$ & & & $\sqrt{ }$ & $\sqrt{ }$ & & $\sqrt{ }$ & & \\
\hline 2 & Brah et al. (2002) & $\sqrt{ }$ & $\sqrt{ }$ & & $\sqrt{ }$ & $\sqrt{ }$ & & & & & $\sqrt{ }$ & & \\
\hline 3 & $\begin{array}{l}\text { Prajogo \& Sohal } \\
\text { (2003) }\end{array}$ & $\sqrt{ }$ & $\sqrt{ }$ & & $\sqrt{ }$ & & & $\sqrt{ }$ & $\sqrt{ }$ & & $\sqrt{ }$ & & \\
\hline 4 & Talavera (2004) & $\sqrt{ }$ & $\sqrt{ }$ & & & & & & & $\sqrt{ }$ & & $\sqrt{ }$ & $\sqrt{ }$ \\
\hline 5 & Sila (2005) & $\sqrt{ }$ & $\sqrt{ }$ & $\sqrt{ }$ & $\sqrt{ }$ & $\sqrt{ }$ & & & & & & & \\
\hline 6 & $\begin{array}{l}\text { Prajago } \\
\text { (2005) }\end{array}$ & $\sqrt{ }$ & $\sqrt{ }$ & & $\sqrt{ }$ & & & $\sqrt{ }$ & $\sqrt{ }$ & & $\sqrt{ }$ & & \\
\hline 7 & Taril et al. (2006) & $\sqrt{ }$ & $\sqrt{ }$ & $\sqrt{ }$ & $\sqrt{ }$ & $\sqrt{ }$ & & & & & & & \\
\hline 8 & Brah \& Lim (2006) & $\sqrt{ }$ & $\sqrt{ }$ & $\sqrt{ }$ & $\sqrt{ }$ & & & & & & & & \\
\hline 9 & $\begin{array}{l}\text { Karuppuasami \& } \\
\text { Gandhinathan (2006) }\end{array}$ & $\sqrt{ }$ & $\sqrt{ }$ & $\sqrt{ }$ & $\sqrt{ }$ & $\sqrt{ }$ & $\sqrt{ }$ & & & & & & \\
\hline 10 & Demirbag (2006) & $\sqrt{ }$ & & & $\sqrt{ }$ & $\sqrt{ }$ & $\sqrt{ }$ & & & & & & \\
\hline 11 & Sila (2007) & $\sqrt{ }$ & $\sqrt{ }$ & $\sqrt{ }$ & $\sqrt{ }$ & $\sqrt{ }$ & & & & & & & \\
\hline 12 & Ou et al. (2007) & $\sqrt{ }$ & $\sqrt{ }$ & $\sqrt{ }$ & $\sqrt{ }$ & $\sqrt{ }$ & & & & & & & \\
\hline 13 & Fryer et al. (2007) & $\sqrt{ }$ & & & $\sqrt{ }$ & $\sqrt{ }$ & $\sqrt{ }$ & & & & & & \\
\hline 14 & Macinati (2008) & $\sqrt{ }$ & & & $\sqrt{ }$ & $\sqrt{ }$ & & & & & & & \\
\hline 15 & Ya'acob (2008) & $\sqrt{ }$ & $\sqrt{ }$ & $\sqrt{ }$ & & $\sqrt{ }$ & & & & & & & \\
\hline 16 & $\begin{array}{l}\text { Al-khalifa et al. } \\
\text { (2008) }\end{array}$ & $\sqrt{ }$ & $\sqrt{ }$ & $\sqrt{ }$ & $\sqrt{ }$ & & $\sqrt{ }$ & & & & & & \\
\hline 17 & Salaheldin (2009) & $\sqrt{ }$ & & & & $\sqrt{ }$ & $\sqrt{ }$ & & & & & & \\
\hline
\end{tabular}


Kelaniya Journal of Human Resource Management

Volume 10-Number 01-January 2015 \& Number 02-July 2015

\begin{tabular}{|c|l|c|c|c|c|c|c|c|c|c|c|c|c|}
\hline \multirow{2}{*}{ No } & \multicolumn{10}{|c|}{ Authors } & \multicolumn{10}{|c|}{ Critical Success Factors of TQM } \\
\cline { 3 - 12 } & & $\mathbf{1}$ & $\mathbf{2}$ & $\mathbf{3}$ & $\mathbf{4}$ & $\mathbf{5}$ & $\mathbf{6}$ & $\mathbf{7}$ & $\mathbf{8}$ & $\mathbf{9}$ & $\mathbf{1 0}$ & $\mathbf{1 1}$ & $\mathbf{1 2}$ \\
\hline 18 & $\begin{array}{l}\text { Satish \& Srinivasan } \\
(2010)\end{array}$ & $\sqrt{ }$ & $\sqrt{ }$ & & $\sqrt{ }$ & $\sqrt{ }$ & & $\sqrt{ }$ & & & $\sqrt{ }$ & & \\
\hline 19 & Malik \& Khan (2011) & & & & & $\sqrt{ }$ & $\sqrt{ }$ & & & & $\sqrt{ }$ & & \\
\hline 20 & $\begin{array}{l}\text { Arumugum \& } \\
\text { Mojtahedzadeh } \\
(2011)\end{array}$ & $\sqrt{ }$ & $\sqrt{ }$ & $\sqrt{ }$ & $\sqrt{ }$ & $\sqrt{ }$ & $\sqrt{ }$ & & & & & & \\
\hline 21 & Zehir et al (2012) & $\sqrt{ }$ & $\sqrt{ }$ & & $\sqrt{ }$ & $\sqrt{ }$ & & & & $\sqrt{ }$ & & & $\sqrt{ }$ \\
\hline
\end{tabular}

Note: (1) Leadership/ Top Management; (2) Customer Focus; (3) Team work; (4) Process Management; (5) Supplier Quality Management; (6) Training; (7) Strategic Planning; (8) People Management; (9) Employee Involvement; (10) Information and Analysis; (11) Incentive and Recognition; and (12) Continuous Improvement Source: Hassan et al. (2012)

Sadikoglu \& Zehir (2010) used eight dimensions to measure TQM practices in studying the effects of innovation and employee performance on the relationship between total quality management practices and firm performance. They are:

- Leadership (L)

- Training (T)

- Employee Management (EM)

- Information and Analysis (IA)

- Supplier Management (SM)

- Process Management (PM)

- Customer focus (CF)

- Continuous improvement (CI)

\subsection{Export Performance}

Export performance of a firm reflects a firm-specific behavior in leveraging its resources and capabilities in an international context at a given point of time. Firm export performance is regarded as one of the key indicators of the success of a firm's export operations.

Conceptual definition of export performance should address each of the two parts: export and performance. Export is defined conceptually as the 
international, marketing related decisions and activities of internationally active firms (Cavusgil \& Nevin, 1981).

In summary, and taking previous research into account, export performance is defined conceptually as the composite outcome of a firm's international sales (Shoham, 1996).

\subsubsection{Measurements of Export Performance}

The two principal modes for looking at export performance involve the use of financial and non-financial measures (Zou and Stan, 1998). In contrast to nonfinancial variables, financial variables are commonly used at the international level (Das, 1994; Evangelista, 1994).

Both financial and non-financial measures can be operationalized in both objective and subjective terms (Evangelista, 1994). However, in most studies, while financial measures (e.g., sales, profit, market share) have been associated with objective terms (normally in absolute terms such as percentage), non-financial measures (e.g., goal achievement, success and importance) have been associated with subjective terms (e.g., managers' perception) (Katsikeas et al., 1996). Several empirical studies have supported the reliability and validity of the use of non-financial and subjective terms to assess export performance.

In short, the use of multiple measures is advisable (Cameron, 1986). Although it is possible to measure export success with one variable, in order to capture the complexity of export success, it is better to construct a scale based on a set of different variables (Bijmolt \& Zwart, 1994; Soham, 1996).

Zou, Taylor, \& Osland (1998) proposed a scale (the EXPERF scale) composed of three dimensions: financial export performance (export profits, export sales and export sales growth), strategic export performance (contribution of the export venture to firm's competitiveness, strategic position and market share), and satisfaction with export performance (perceived success of the venture, satisfaction with the venture and degree to which the venture is meeting expectations). 


\subsection{Relationship between TQM Practices and Organizational Performance}

On one hand, Hassan et al, (2012) found that TQM practices positively impact on firm performance. On the other hand, TQM tools and techniques (Incentive and Recognition System, Process, Monitoring and Control and Continuous Improvement) and Behavioral factors (Fact based-management, top management's commitment to quality, employee involvement and customer focus) contribute to the successful implementation of TQM. The study reports that successful adoption and implementation of TQM practices results in improving the performance of organization. The main implication of the findings for managers is that with TQM practices, manufacturing organizations are more likely to achieve better performance in customer satisfaction, employee relations, quality and business performance than without TQM practices.

According to a study conducted by Demirbag, Tatoglu, Tekinkus, \& Zaim, (2006) an analysis of the relationship between TQM implementation and organizational performance: Evidence from Turkish SMEs operating in Turkish textile industry reveals that there is a strong positive relationship between TQM practices and non-financial performance of SMEs, while there is only weak influence of TQM practices on financial performance of SMEs. With only a mediating effect of non-financial performance that the TQM practices has a strong positive impact on financial performance of SMEs.

Most previous studies show a positive relationship between TQM practices and business performance (Bou \& Beltrán, 2005; Gunday et al., 2011; Jun et al., 2006; Miyagawa \& Yoshida, 2010).

However, there are also studies that show TQM did not improve the business performance (Corredor \& Goñi, 2011; Demirbag et al., 2006). Some of the findings also partially correlated with the business performance (Arumugam et al., 2008; Feng et al., 2006). 


\section{Methodology}

\subsection{Study Framework}

Based on the literature above, the researcher has selected the following list of eight main practices of TQM implementation for this study adopted from the dimensions identified by Sadikoglu \& Zehir (2010). And the export performance was measured by using EXPERF scale developed by Zou at el. (1998).

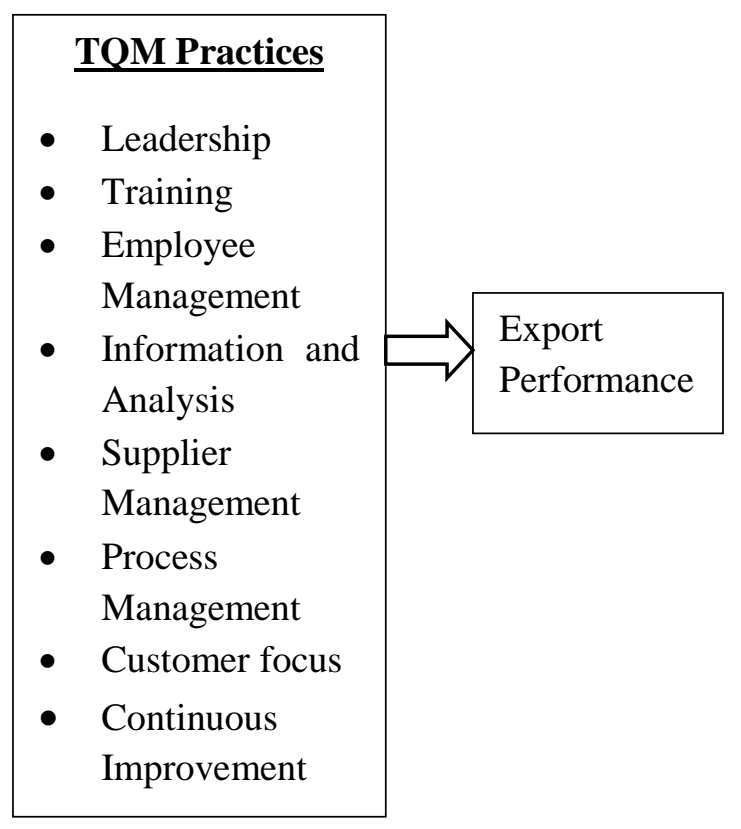

Figure 01: Conceptual framework of the Study

\subsection{Hypotheses of the Study}

According to the conceptual framework the following nine hypotheses were advanced to be tested with empirical data.

Hypothesis 1: Relationship between TQM Practices and Export Performance

Hypothesis 2: Relationship between Leadership and Export Performance Hypothesis 3: Relationship between Training and Export Performance 
Hypothesis 4: Relationship between Employee Management and Export Performance

Hypothesis 5: Relationship between Information \& Analysis and Export Performance

Hypothesis 6: Relationship between Supplier Management and Export Performance

Hypothesis 7: Relationship between Process Management and Export Performance

Hypothesis 8: Relationship between Customer Focus and Export

Performance

Hypothesis 9: Relationship between Continuous Improvement and Export Performance

\subsection{Data Collection}

The sample of the study consists of 65 apparel exporters randomly selected from the 112 registered apparel exporters. Simple random sampling technique was used to select the sample from the population.

The relevant data for the purpose of this study were collected from primary and secondary sources. Primary data were collected through a five point likert scale questionnaire and secondary data were collected from published documents. The reliability of the scale for the study was established using Cronbach's coefficient alpha.

\subsection{Data Analysis}

Univariate analysis has done for Total Quality Management Practices dimensions, and Export Performance dimensions. The bivariate analysis and graphs are used for testing hypothesizes to analyze the relationship between Total Quality Management Practices and Export Performance.

\subsubsection{Levels of Total Quality Management Practices}

Mean values were taken to identify the levels of TQMP. According to research results, $43(74 \%)$ of the respondents have very high level of TQMP out of 58 and $26 \%$ have high level of TQMP. 
Kelaniya Journal of Human Resource Management

Volume 10-Number 01-January 2015 \& Number 02-July 2015

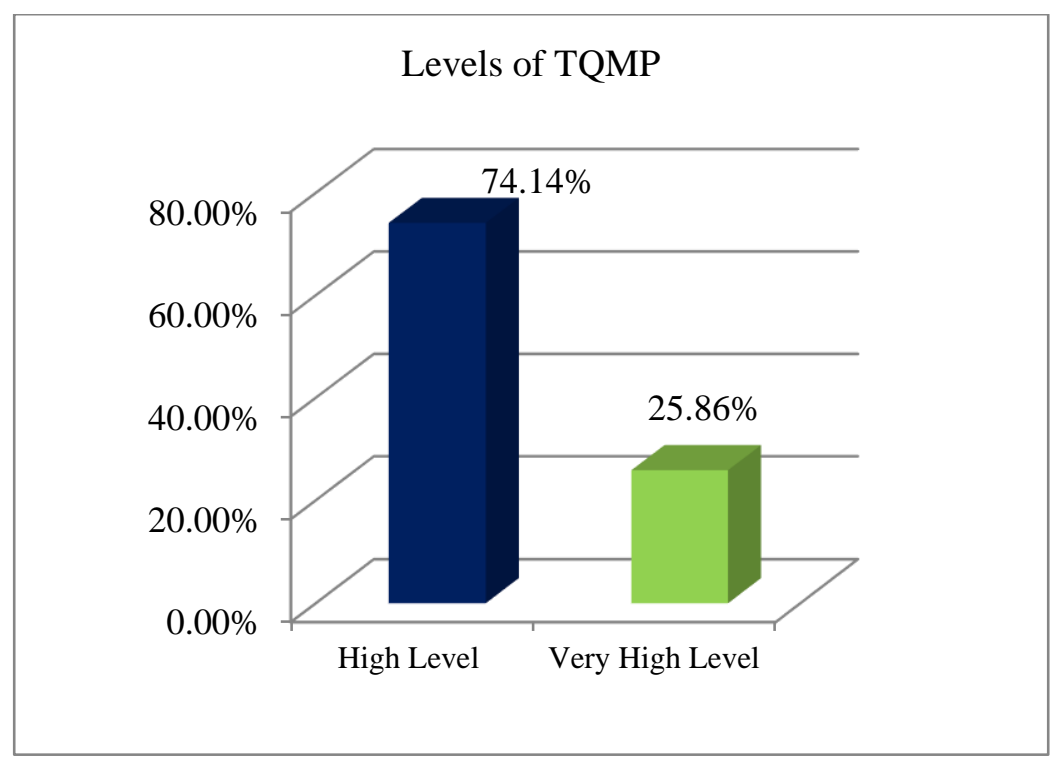

\section{Figure 02: Levels of TQMP}

Source: Survey Data

TQMP was measured by using eight dimensions as leadership, training, employee management, information and analysis, supplier management, process management, customer focus and continuous improvement. And the levels of each practices performed by apparel exporters of Sri Lanka is as follows.

Table 02: The Levels of TQMP

\begin{tabular}{|l|c|c|c|}
\hline \multirow{2}{*}{\multicolumn{1}{|c|}{ Item }} & \multicolumn{3}{|c|}{ Level of TQMP } \\
\cline { 2 - 4 } & Moderate & High & $\begin{array}{c}\text { Very } \\
\text { High }\end{array}$ \\
\hline Leadership & $0 \%$ & $64 \%$ & $36 \%$ \\
\hline Training & $0 \%$ & $55 \%$ & $45 \%$ \\
\hline $\begin{array}{l}\text { Employee } \\
\text { Management }\end{array}$ & $2 \%$ & $83 \%$ & $15 \%$ \\
\hline $\begin{array}{l}\text { Supplier } \\
\text { Management }\end{array}$ & $0 \%$ & $64 \%$ & $36 \%$ \\
\hline $\begin{array}{l}\text { Information and } \\
\text { Analysis }\end{array}$ & $0 \%$ & $67 \%$ & $33 \%$ \\
\hline
\end{tabular}


Kelaniya Journal of Human Resource Management

Volume 10-Number 01-January 2015 \& Number 02-July 2015

\begin{tabular}{|l|c|c|c|}
\hline \multirow{2}{*}{\multicolumn{1}{|c|}{ Item }} & \multicolumn{2}{c|}{ Level of TQMP } \\
\cline { 2 - 4 } & Moderate & High & $\begin{array}{l}\text { Very } \\
\text { High }\end{array}$ \\
\hline $\begin{array}{l}\text { Process } \\
\text { Management }\end{array}$ & $3 \%$ & $83 \%$ & $14 \%$ \\
\hline Customer Focus & $0 \%$ & $47 \%$ & $53 \%$ \\
\hline $\begin{array}{l}\text { Continuous } \\
\text { Improvement }\end{array}$ & $19 \%$ & $59 \%$ & $22 \%$ \\
\hline TQMP & $\mathbf{0 \%}$ & $\mathbf{7 4 \%}$ & $\mathbf{2 6 \%}$ \\
\hline
\end{tabular}

Source: Survey Data

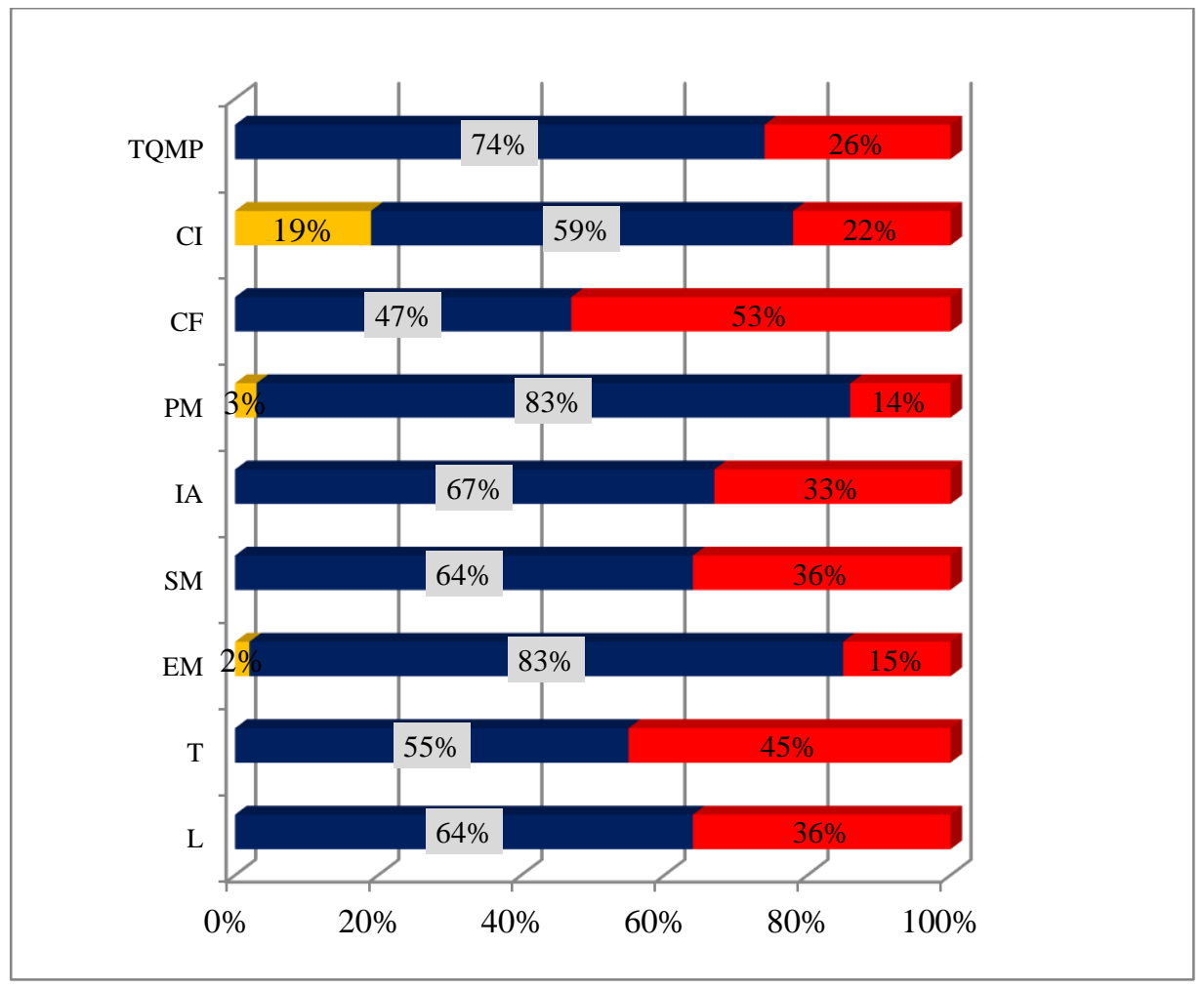

Figure 03: Summary of TQMP

Source: Survey Data 


\subsubsection{Hypotheses Testing}

Following table 03 shows the results summary of the hypotheses tested. Accordingly all alternative hypotheses except one have rejected.

Table 03: Summary Table of Hypothesis Testing of TQMP on EP

\begin{tabular}{|l|l|l|l|l|}
\hline \multicolumn{1}{|c|}{ Hypotheses } & \multicolumn{1}{|c|}{$\begin{array}{l}\text { R } \\
\text { value }\end{array}$} & $\begin{array}{c}\text { Sig } \\
\text { Value }\end{array}$ & \multicolumn{1}{|c|}{ H1 } & $\begin{array}{l}\text { Relationship } \\
\text { Type and } \\
\text { Degree of } \\
\text { Correlation }\end{array}$ \\
\hline $\begin{array}{l}\text { H1: There is a relationship } \\
\text { between TQMP and EP }\end{array}$ & 0.739 & .000 & Accepted & $\begin{array}{l}\text { Moderate } \\
\text { Positive }\end{array}$ \\
\hline $\begin{array}{l}\text { H2: There is a relationship } \\
\text { between L and EP }\end{array}$ & $.510\left(^{* *}\right)$ & .000 & Accepted & $\begin{array}{l}\text { Moderate } \\
\text { Positive }\end{array}$ \\
\hline $\begin{array}{l}\text { H3: There is a relationship } \\
\text { between T and EP }\end{array}$ & $.460(* *)$ & .000 & Accepted & $\begin{array}{l}\text { Moderate } \\
\text { Positive }\end{array}$ \\
\hline $\begin{array}{l}\text { H4: There is a relationship } \\
\text { between EM and EP }\end{array}$ & $.511(* *)$ & .000 & Accepted & $\begin{array}{l}\text { Moderate } \\
\text { Positive }\end{array}$ \\
\hline $\begin{array}{l}\text { H5: There is a relationship } \\
\text { between IA and EP }\end{array}$ & .196 & .139 & Rejected & $\begin{array}{l}\text { Not } \\
\text { Significant }\end{array}$ \\
\hline $\begin{array}{l}\text { H6: There is a relationship } \\
\text { between SM and EP }\end{array}$ & $.593(* *)$ & .000 & Accepted & $\begin{array}{l}\text { Moderate } \\
\text { Positive }\end{array}$ \\
\hline $\begin{array}{l}\text { H7: There is a relationship } \\
\text { between PM and EP }\end{array}$ & $.491(* *)$ & .000 & Accepted & $\begin{array}{l}\text { Moderate } \\
\text { Positive }\end{array}$ \\
\hline $\begin{array}{l}\text { H8: There is a relationship } \\
\text { between CF and EP }\end{array}$ & $.638(* *)$ & .000 & Accepted & $\begin{array}{l}\text { Moderate } \\
\text { Positive }\end{array}$ \\
\hline $\begin{array}{l}\text { H9: There is a relationship } \\
\text { between CI and EP }\end{array}$ & $.567(* *)$ & .000 & Accepted & $\begin{array}{l}\text { Moderate } \\
\text { Positive }\end{array}$ \\
\hline
\end{tabular}

Source: Survey Data

\subsubsection{Regression Analysis}

Simple regression was conducted to identify the impact of TQMP and EP. Table 04 and table 05 summarize the results of the regression analysis. 
Table 04: Results of Regression Analysis

\begin{tabular}{|c|c|c|c|c|}
\hline Model & $\mathrm{R}$ & R Square & $\begin{array}{c}\text { Adjusted R } \\
\text { Square }\end{array}$ & $\begin{array}{c}\text { Std. Error of the } \\
\text { Estimate }\end{array}$ \\
\hline 1 & $.739^{\mathrm{a}}$ & .546 & .538 & 2.206 \\
\hline
\end{tabular}

a. Predictors: (Constant), TQMP

Source: Survey Data

$\mathrm{R}^{2}=0.546$ indicates that the two variables are significantly related. $55 \%$ of the EP is due to the changes in the TQMP. In other words $45 \%$ of variation in EP is due to factors other than the TQMP.

Table 05: Model summary of Regression Analysis

\begin{tabular}{|ll|c|c|c|c|c|}
\hline \multicolumn{1}{|c|}{ Model } & $\begin{array}{c}\text { Sum of } \\
\text { Squares }\end{array}$ & df & $\begin{array}{c}\text { Mean } \\
\text { Square }\end{array}$ & F & Sig. \\
\hline 1 & Regression & 327.930 & 1 & 327.930 & 67.374 & $.000^{\mathrm{a}}$ \\
& Residual & 272.570 & 56 & 4.867 & & \\
Total & 600.500 & 57 & & & \\
\hline
\end{tabular}

a. Predictors: (Constant), TQMP

b. Dependent Variable: EP

Source: Survey Data

The table shows that the independent variables statistically significantly predict the dependent variable, $F(1,56)=67.347, p<.0005$.

\subsubsection{Multiple Linear Regression Analysis}

Multiple linear regression analysis was used to recognize the relative importance of the TQMP on EP. Table 06 summarizes the results of the analysis. 
Table 06: Model Summary

\begin{tabular}{|c|c|c|c|c|}
\hline Model & $\mathrm{R}$ & $\begin{array}{c}\mathrm{R} \\
\text { Square }\end{array}$ & $\begin{array}{c}\text { Adjusted } \\
\mathrm{R} \\
\text { Square }\end{array}$ & $\begin{array}{c}\text { Std. Error } \\
\text { of the } \\
\text { Estimate }\end{array}$ \\
\hline 1 & .822 & .675 & .622 & 1.996 \\
\hline
\end{tabular}

a. Predictors: (Constant), Continuous Improvement, Information and Analysis, Training, Supplier Management, Customer Focus, Employee Management, Leadership, Process Management

b. Dependent Variable: EP

Source: Survey Data

The value of $R$, the multiple correlation coefficient of 0.822 indicates a good level of prediction. $\mathrm{R}$ square value the coefficient of determination which is the proportion of variance in the dependent variable that can be explained by the independent variables which indicates $67.5 \%$ of the variability in EP explained by TQMP.

Table 07: Results of Multiple Regression Analysis

\begin{tabular}{|l|l|l|l|l|l|l|}
\hline Model & & \multicolumn{2}{|c|}{$\begin{array}{c}\text { Unstandardized } \\
\text { Coefficients }\end{array}$} & $\begin{array}{c}\text { Standardized } \\
\text { Coefficients }\end{array}$ & $\mathbf{t}$ & \multicolumn{1}{|c|}{ Sig. } \\
\hline & & B & $\begin{array}{c}\text { Std. } \\
\text { Error }\end{array}$ & Beta & B & $\begin{array}{c}\text { Std. } \\
\text { Error }\end{array}$ \\
\hline 1 & (Constant) & -8.675 & 5.557 & & -1.561 & .125 \\
\hline & L & .163 & .190 & .106 & .858 & .395 \\
\hline & T & .118 & .176 & .066 & .670 & .506 \\
\hline & EM & -.102 & .145 & -.089 & -.701 & .486 \\
\hline & IA & .040 & .192 & .019 & .210 & .835 \\
\hline & SM & .763 & .237 & .340 & 3.219 & .002 \\
\hline & PM & .077 & .221 & .044 & .348 & .729 \\
\hline & CF & .654 & .177 & .377 & 3.689 & .001 \\
\hline & CI & .972 & .396 & .297 & 2.455 & .018 \\
\hline
\end{tabular}

Source: Survey Data 
Unstandardized coefficients indicate how much the dependent variable varies with an independent variable when all other independent variables are held constant. According to the sig values of the dimensions of independent variable, only three dimensions are significant which indicates $\mathrm{p}<.05$, where the coefficients are statistically significantly different to 0 (zero).

It indicates that only customer focus, supplier management and continuous improvement are statistically significantly predicted EP.

\section{Findings and Discussion}

The major objective of the study was to identify the impact of Total Quality Management Practices on Export Performance and the findings proved that there is a significant impact of total quality management practices on export performance and the impact of TQMP on EP is profound.

Accordingly, the customer focus, supplier management and continuous improvement were the most significant dimensions on the impact of export performance whereas the other five dimensions except information and analysis; employee management, leadership, process management and training except information and analysis have significant relation with export performance.

\subsection{Leadership}

Top management support is significantly associated with export performance and this finding is consistent with previous studies of Arumugam et al., (2008), they find positive relationship between top management support and quality performance.

According to Simatupang \& White (1998) top management support serve as a positive foundation for the company's whole processes that ultimately affect organizational performance. However, this finding is not consistent with previous studies of Choi \& Eboch (1998) and Kannan \& Tan (2005). These studies find that one of TQM practice namely leadership has nonsignificant relationship with quality performance and financial performance. Similarly, Mehmood, Ahmad, \& Qadeer, 2014 revealed that the top management support has no statistical significance for predicting the performance. Therefore, in Sri Lankan apparel export industry, the top 
management promotes effective decision making in quality implementation and maintenance for effective enhancement of performance.

\subsection{Training and Employee Management}

Employee management is significantly associated with export performance. This result is consistent with the study of Abdullah \& Sidin, (2010) which finds that soft TQM elements such as supplier relationships, people management and training and education positively influence the firm performance. This finding is also consistent with Lorente, Dewhurst, \& Dale, (1999) where they suggest that well trained employees are open to bring novel ideas for innovations and performance enhancement. Employee involvement is a key dimension for successful TQM implementation and it has great importance in apparel industry, where the international market is of extreme importance and therefore TQM implementation through various quality standards certifications is often demanded. This result is as per expectations, teamwork and supportive employee management techniques increases efficiency and problem solving abilities of employees that ultimately accumulate into organizational performance at the sight of exporters the export performance.

Another study conducted by Mehmood et al, 2014 from a self-administrative survey from 90 organizations of textile sector in Pakistan, revealed that the continuous improvement and the employee involvement are the most critical dimensions for predicting organizational performance.

\subsection{Information and Analysis}

Findings of IA on EP is not consistent with the previous study of Miyagawa \& Yoshida (2010) which they made a conclusion that the extent of implementation of TQM factors including leadership, quality of information, implementation of the strategies, human resource management $\&$ meeting expectation of the customers has a significant effect on the performance.

However, according to a study conducted by Ahmad, Zakuan \& Jusoh (2013) on the Relationships between The Extent of TQM Practices and The Importance on Business Performance, the final ranking is finalized based on the practices level and its importance to business performance as follows; (1) Management strategy and policy; (2) Customer focus; (3) Continuous 
improvement; (4) Supplier management; (5) Work process; (6) Business ethics; (7) Top management leadership; (8) Information and analysis; (9) Human resource development; (10) New product management.

In another study done in Australia, Samson and Terziovski (1999) conclude that the hard factors such as planning and process management, information and analysis, are neither significantly related or negatively related.

\subsection{Supplier Management}

Supplier management is significantly associated with export performance. This result is consistent with the study of Abdullah et al. (2010) which finds that supplier relationships, people management and training and education positively influence the firm performance.

Other than that in previous empirical studies, it shows the important of the relationship between suppliers and the organization performance (Ahire et al. 1996).

\subsection{Process Management}

Process management is significantly associated with export performance. This result is consistent with the study of Ahmad et al. (2013) on The Relationships Between the extent of TQM Practices and the Importance on Business Performance which found that work process for TQM practices is positively correlated with business performance.

However, a study done in Australia, Samson \& Terziovski (1999) conclude that the hard factors such as planning and process management, information and analysis, are neither significantly related nor negatively related.

\subsection{Customer Focus}

The results of the study are consistent with the other studies where scholars find that TQM elements such as customer focus and customer satisfaction positively affects organizational performance (Agus, 2004; Brah et al., 2002; Fotopoulos and Psomas, 2010). Chong \& Rundus (2004) also found that TQM practices of customer focus are positively associated with organizational performance. 
In Sri Lankans' apparel industry context the management incorporate the quality related complaints of the customers so that their overall performance may be improved. And as a result Sri Lanka's top three apparel companies are already amongst the world's 50 most important suppliers, and the industry has sustained over US $\$ 3$ billion in export revenue for five consecutive years.

This long term relationships with reputed multinational retailers who have identified standards of manufacture and compliance have led to economic sustainability implies the customer focus. The industry possesses an impressive partnership portfolio which includes world renowned labels such as Victoria's Secret, Gap, and Liz Claiborne, Next, Jones New York, Nike, Tommy Hilfiger, Pink, Triumph, Ann Taylor, Speedo, Abercrombie \& Fitch, Land's End, Marks \& Spencer \& Intimissi.

However this finding is not consistent with the Prajogo \& Sohal (2001), they report that a customer orientation restrain the organizations to become a broad minded which stop their ability to innovate and prevent them to become a market leader. Similarly, Mehmood et al, (2014) revealed that the customer focus has no statistical significance for predicting the performance.

\subsection{Continuous Improvement}

Continuous improvement is significantly associated with organizational performance. This result is consistent with previous studies where researchers find that the continuous improvement in quality standards has positive impact on different types of performance (Fuentes et al., 2006; Rahman and Bullock, 2005; Sadikoglu \& Zehir, 2010). This finding in the context of the present study (i.e.apparel exporters of Sri Lanka) suggests a convergence trends on the phenomenon understood and predicted through this result.

Based on the above discussion the study reveals the importance of TQM dimensions on export performance in apparel exporters of Sri Lanka. The analytical results confirm the significant and positive association of one off the eight TQM dimensions (information and analysis) with export performance. Furthermore, it is determined that TQM dimensions such as customer focus continuous improvement and employee management are major dimensions of performance of apparel industry. 


\subsection{Relationship between TQM and EP}

Most previous studies show a positive relationship between TQM practices and business performance (Bou \& Beltrán, 2005; Gunday et al., 2011; Jun et al., 2006; Miyagawa \& Yoshida, 2010). And also some studies reveal that there is a strong relationship between TQM and business performance as in previous studies (Agus \& Hassan, 2011; Arumugam et al., 2008; Miyagawa \& Yoshida, 2010; Ahmad et al., 2012)

Accordingly this study has proved that there is a significant positive relationship between TQMP and EP. It indicates that when TQMP is high, it is caused to increase the EP which indicates that greater the implementation of TQMP greater the EP. However, there are also studies that show TQM did not improve the business performance (Corredor \& Goñi, 2011; Demirbag, Tatoglu et al., 2006). Some of the findings also partially correlated with the business performance (Arumugam et al., 2008; Feng et al., 2006).

\section{Conclusion}

In today's highly competitive market, business performance is one of the critical factors for companies to survive in the global marketplace. The concept of total quality management (TQM) has been developed as a result of intense global competition for improving business performance. Many previous studies discussed about TQM and the extent of the TQM practices, however, almost previous works were given less emphasis on the relationships between TQMP and its importance to export performance based on the individual dimensions in TQM, which is identified as theoretical gap.

In this study it examined the impact of TQMP on EP of apparel exporters of Sri Lanka. Based on all the findings of the present study confirms that the TQMP generates a significant impact on EP of the apparel exporters of Sri Lanka.

The study supported the hypothesis that there is a relationship between TQMP and EP. However it is found that there is a significant moderate positive relationship between TQMP and EP and it concludes that increasing TQMP will result in increasing the EP of the apparel exporters. Further, the 
study concluded that the level of TQMP implemented by apparel exporters in Sri Lanka is at a high level and the export performance is also at a high level.

\section{References}

Abdul, A. A., and Md. Sidin, S. (2010). Export performance on the Malaysian wooden furniture industry: An empirical study. Journal of International Food and Agribusiness Marketing, 22 (1\&2), 52-69.

Agus, A. (2004). TQM as a focus for improving service performance and customer satisfaction: An empirical study on a public service sector in Malaysia. Total Quality Management and Business Excellence, 15(5-6), 615-628.

Ahire, S.L., Golhar, D.Y., Waller, M.A., (1996). Development and validation of TQM implementation constructs. Decision Sciences 27 (1), 23-56.

Ahmad, M. F., Zakuan, N., Jusoh, a., \& Takala, J. (2013). Review of Relationship between TQM and Business Performance. Applied Mechanics and Materials, 315, 166170.doi:10.4028/www.scientific.net/AMM.315.166

Arumugam, V., Ooi, K. B., \& Fong, T. C. (2008). TQM practices and quality management performance: An investigation of their relationship using data from ISO 9001: 2000 firms in Malaysia. The TQM Journal, 20(6), 636-650.

Atkinson, P. E. and Naden, J. (1989). Total Quality Management: Eight Lessons to Learn from Japan. Management Services. 33(3). 6-10

Bijmolt, T. H. A., \& Zwart, P. S. (1994). The impact of internal factors on the export success of Dutch small and medium-sized firms. Journal of Small Business Management, 32(2), 69-83.

Bou, J. C., \& Beltrán, I. (2005). Total quality management, highcommitment human resource strategy and firm performance: An empirical study. Total Quality Management \& Business Excellence, 16(1), 71-86. 
Cameron, K. S. (1986). Effectiveness as paradox: Consensus and conflict in conceptions of organizational effectiveness. Management Science, 32(5), 539-553.

Cavusgil, S. T., \& Nevin, J. R. (1981). State-of-art in international marketing: An assessment. In Annual review of marketing (Ennis, Ben M.; Roering, Kenneth J. ed., pp. 195-216). Chicago: American Marketing Association.

Choi, T.Y. and Eboch, K. (1998). The TQM paradox: Relations among TQM practices, plant performance and customer satisfaction. Journal of Operations Management, 17(1), 59-75.

Chong, V.K., and Rundus,M. J., (2004).Total quality management, market competition and organizational performance. The British Accounting Review, 36, 155-172.

Corredor, P., \& Goñi, S. (2011). TQM and performance: Is the relationship so obvious? Journal of Business Research, 64(8), 830-838.

Das, M. (1994). Successful and unsuccessful exporters from developing countries: some preliminary findings. European Journal of Marketing, 28(12), 19-33. doi: 10.1108/03090569410074237

Demirbag, M., Tatoglu, E., Tekinkus, M., \& Zaim, S. (2006). An analysis of the relationship between TQM implementation and organizational performance: evidence from Turkish SMEs. Journal of manufacturing technology management, 17(6), 829-847.

Evangelista, F. U. (1994). Export performance and its determinants: Some empirical evidence from Australian manufacturing firms. In Advances in International Marketing (Cavusgil, S.T. \& Axinn, C. ed., Vol. 6 pp. 207-229). Greenwich, Conn: JAI Press.

Feng, J., Prajogo, D. I., Chuan Tan, K., \& Sohal, A. S. (2006). The impact of TQM practices on performance: A comparative study between Australian and Singaporean organizations. European Journal of Innovation Management, 9(3), 269-278. 
Fotopoulos, C. V., and Psomas, E. L. (2010). The structural relationships between TQM factors and organizational performance. The TQM Journal, 22(5), 539-552.

Fuentes, M. M. F.,Saez, A. C. A.,Montes,F.J.L.,2004.The impact of environmental characteristics on TQM principles and organizational performance.Omega32 (6), 425-442.

Goh, P.L. and Ridgway, K. (1994). The implementation of total quality management in small and medium-sized manufacturing companies. TQM Magazine, Vol. 6 No. 2, pp. 54-60.

Gunday, G., Ulusoy, G., Kilic, K., \& Alpkan, L. (2011). Effects of innovation types on firm performance. International Journal of Production Economics, 133(2), 662-676.

Hallak, J.C. (2003). "The Effect of Cross-Country Differences in Product Quality on the Direction of International Trade.” RSIE Working.

Hassan, M., A.A. Malik and M.F. Faiz, 2012. An empirical assessment of service quality and its relationship with customer loyalty. Evidence from the telecom sector of Pakistan. International Journal of Asian Social Sciences, 2(6).

Jun, M., Cai, S., \& Shin, H. (2006). TQM practice in maquiladora: Antecedents of employee satisfaction and loyalty. Journal of operations management, 24(6), 791-812.

Juran, J. M. \& Godfrey, B. (2000): Juran“es quality handbook. New York: McGraw-Hill.

Kapuge, A.M and Smith, M. (2005). Management Practices and Performance Reporting in the Sri Lankan Apparel Sector. Management Auditing Journal, 22(3), 303-315.

Katsikeas, C. S., Piercy, N. F., \& Ionnidis, C. (1996). Determinants of export performance in a European context. European Journal of Marketing, 30(6), 6-35.

Kelegama, S. (2009). Ready-made Garment Exports from Sri Lanka. Journal of Contemporary Asia, 579-596. 
Linder, S. (1961). An Essay on Trade and Transformation, (Stockholm: Almqvist \& Wiksell).

Lorente, A. R. M., Dewhurst, F. \& Dale, B. G. (1999). TQM and Business Innovation", European Journal of Innovation Management, 2(1), 1219.

Mehmood, S., Qadeer, F. \& Ahmad, A. (2014). Relationship between TQM Dimensions and Organizational Performance, Pakistan Journal of Commerce and Social Sciences, 8(3), 662-679.

Miyagawa, M., \& Yoshida, K. (2010). TQM practices of Japanese-owned manufacturers in the USA and China. International Journal of Quality \& Reliability Management, 27(7), 736-755.

Prajogo, D.I., Sohal, A.S. (2001).TQM and innovation: a literature review and research framework.Technovation21, 539-558.

Rahman, S.,Bullock,P. (2005). Soft TQM, hard TQM, and organizational performance relationships: an empirical investigation.Omega33, 7383.

Sadikoglu, E., and Zehir, C. (2010). "Investigating the effect of innovation and employee performance on relationship between TQM practices and firm performance": An empirical study of Turkish firms, International Journal of Production Economics, 1-14.

Samson, D., Terziovski, M. (1999). The relationship between total quality management practices and operational performance. Journal of Operations Management 17 (4), 393-409.

Shoham, A. (1996). Marketing-mix standardization: Determinants of export performance. Journal of Global Marketing, 10(2), 53-73.

Simatupang, T.M. and White, A.J. (1998). A policy resolution model for knowledge acquisition in quality management. Total Quality Management, 9(8), 767-779.

Uzumeri, M. V. (1997). ISO 9000 and other meta standards: principles for management practices. Academy of Management Executive, 11(1), 21-36. 
Kelaniya Journal of Human Resource Management

Volume 10-Number 01-January 2015 \& Number 02-July 2015

Valos, M. and Baker, M. (1996). Developing an Australian model of export marketing performance determinants. Marketing Intelligence and Planning, 14(3), 11-20.

Zou, S., and Stan, S. (1998). The determinants of export performance: a review of the empirical literature between 1987 and 1997. International Marketing Review, 15(5), 333-356.

Zou, S., Taylor, C. R., \& Osland, G. E. (1998). The EXPERF scale: a crossnational generalized export performance measure. Journal of International Marketing, 6(3), 37-58. 